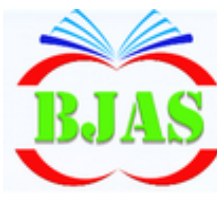

ISSN $1814-5868$
Available online at http://bajas.edu.iq

https://doi.org/10.37077/25200860.2022.35.1.08

College of Agriculture, University of Basrah

Basrah J. Agric. Sci., 35(1): 94-105, 2022
Basrah Journal

of Agricultural

Sciences

E-ISSN: 2520-0860

\title{
Production of Hydrolyzed Collagen from Common Carp Cyprinus carpio L. Scales by Synergistic Enzyme Systems
}

\author{
Hala H. M. Al-Abadi ${ }^{1}$ \& Wasan K. A. AI-Temimi2* \\ ${ }^{1,2}$ Department of Food Science, College of Agriculture, University of Basrah, Iraq \\ *Corresponding author email: wasan.abdul_razzaqi@uobasrah.edu.iq \\ Received $25^{\text {th }}$ July 2019; Accepted 11 ${ }^{\text {th }}$ October 2021; Available online $4^{\text {th }}$ March 2022
}

\begin{abstract}
Fish skin, bones and scales are a good source of collagen, for the sake of exploitation these fish wastes of high commercial worth and convert them into food, therapeutic and pharmaceutical products. Therefore, the study included extracting collagen with acetic acid at a concentration $0.5 \mathrm{M}$ and pepsin enzyme $0.1 \%$ from fish Cyprinus carpio scales and then producing hydrolyzed collagen protein. Chemical content of the scales was estimated from the percentage of moisture, protein, fat and ash, as it was found $(55.36,35.85,2.47$ and 5.99) \%, respectively. The metallic elements represented by $(\mathrm{Ca}, \mathrm{P}, \mathrm{Fe}$ and $\mathrm{Zn})$, they reached (153430, 1887.5, 71.455 and 48.045) $\mu \mathrm{g} . \mathrm{g}^{-1}$. The collagen yield by the two methods mentioned above was $16.40 \%$ and $5.30 \%$, respectively. Diagnosis of collagen extracted with acid using FT-IR technique and determination of the active groups in it, the presence of amides A, B, I, II and III was observed at frequencies 3413.39, 2924.52, 1653.66, 1548.56 and $1240 \mathrm{~cm}^{-1}$, respectively. Hydrolysed collagen was prepared using Collagenase enzyme followed by Pepsin enzyme, the highest degree of hydrolysis reached $43.56 \%$ after four hours. The electrophoresis of collagen extracted with acid and enzyme was carried out, as three bundles of collagen $\alpha 1, \alpha 2$ and $\beta$ were obtained with weights $(126,100$ and 180) KD, respectively.
\end{abstract}

Keywords: Extracted Collagen, Fish scales, Diagnosed bioactive compounds, Protein hydrolysates.

\section{Introduction}

Fish wastes have received considerable attention because they contain many components, including amino acids, fatty acids, vitamins and mineral elements. Fish skin, bones, and scales are good sources of collagen, and utilizing these fish by-products minimizes pollution while also converting these wastes into high-value commodities. (Arvanitoyannis \& Kassaveti, 2008; Olatunji \& Denloye, 2017).
Collagen is the basic protein of connective tissue, as it consists of three polypeptide chains wrapped in a helix, in which proline or hydroxyproline is the basic structure to form the helix. Collagen and its peptides have been used in many foods, medical and pharmaceutical applications due to their biocompatibility and good biodegradability (Shoulders \& Raines, 2009; Sorushanova et al., 2018). 
Al-Abadi \& AI-Temimi / Basrah J. Agric. Sci., 35(1), 94-105, 2022

Proteolytic enzymes are the products of the hydrolysis of proteins using chemical and enzymatic methods aim to obtain peptides, or amino acids of technological importance, as these products used in the field of food, pharmaceutical and medical industries (Udenigwe \& Aluko, 2011). Many studies have indicated that hydrolysed collagen is easy to digest and absorb, as well as having biological efficacy, as it can be taken orally in the form of amino acids or peptides, as it reaches through the small intestine and the bloodstream to the rest of the body parts that work on the formation of collagen fibers. Peptides also act the short chain linkage of fibroblast receptors and stimulates the production of new collagen, hyaluronic acid and elastin.

The hydrolysate is characterised by low viscosity, colourless and odorless with its ability to emulsify foam and dissolve (Denis et al., 2008). Given the importance of the nutritional, medicinal and commercial importance of collagen and its use as an alternative source for pig and cow collagen because it is disease-free and far from religious beliefs. Therefore, the study aimed to extract collagen from carp fish scales. Study its characteristics, and preparing hydrolysed collagen with collagenase enzyme and pepsin.

\section{Material and Methods}

Common carp Cyprinus carpio L. was collected from fish breeders in Basrah province, Iraq, within average weight and lengtharound 1900-2000 $\mathrm{g}$ and $(45-50) \mathrm{cm}$, respectively. After transporting them to the laboratory, the scales were removed with a knife, then washed with cold water and the scales were cut into small pieces, which were kept in polyethylene bags at freezing temperature until use.

Acid Solubilized Collagen (ASC)
Collagen was extracted according to the method of Zhang et al. (2010) with some modification. The scales were immersed in $0.5 \mathrm{M} \mathrm{NaOH}$ solution at a mixing ratio of $1: 10 \mathrm{w} / \mathrm{v}$ for 48 hours with stirring at a temperature of $4{ }^{\circ} \mathrm{C}$ and replacing the solution every eight hours to remove non-collagenous proteins. The scales were washed with cold water until the $\mathrm{pH}$ reached neutrality, and then scales were immersed in 0.5 M EDTA$2 \mathrm{Na}$ solution at $\mathrm{pH} 7.4$ for 48 hours at ratio $1: 10 \mathrm{w} / \mathrm{v}$ with stirring and replacing the solution, every 48 hours, The scales were rinsed several times in cold water before being immersed in $0.5 \mathrm{M}$ acetic acid at a 1:15 w/v mixing ratio for 48 hours with agitation. Filtered the solution via cheesecloth, then added $2.5 \mathrm{M} \mathrm{NaCl}$ Tris-solution to the filtrate. At $\mathrm{pH} 7$, the HCL concentration was $0.05 \mathrm{M}$, and the sample was centrifuged 10,000 times for 30 minutes at $4^{\circ} \mathrm{C}$. The precipitate was placed in 8-14 KD dialysis bags for 12 hours in $0.1 \mathrm{M}$ acetic acid solution, then distilled water was replenished and immersed for 48 hours, with replacement every six hours, the samples were lyophilised using the Freeze Dryer (Christ, Germany).

\section{Pepsin Solubilized Collagen (PSC)}

Collagen was extracted using the Nagai et al. (2001) with some modification. The ASC residues were collected and suspended in $0.5 \mathrm{M}$ acetic acid, followed by the addition of 0.1 $\%$ pepsin enzyme and stirring for two days. The samples were then centrifuged at $4^{\circ} \mathrm{C}$ for one hour at 10,000 cycles. The supernatants were taken and dialysed against $0.02 \mathrm{M} \mathrm{Na} \mathrm{NPO}_{4}(\mathrm{PH}$ 7.2) for three days to inhibition pepsin. The precipitate was dissolved in $0.5 \mathrm{M}$ acetic acid and placed in 8-14 KD dialysis bags in $0.1 \mathrm{M}$ acetic acid solution for 12 hours, the acid was replaced with distilled water and immersed for 48 hours, with replacement every six 
Al-Abadi \& AI-Temimi / Basrah J. Agric. Sci., 35(1), 94-105, 2022

hours, and then the samples were lyophilised using the Freeze Dryer (Christ, Germany).

\section{Chemical content}

Chemical content of scales and collagen included moisture, protein, fat and ash was

\section{Collagen Yield}

Collagen yield was estimated according to the Fehing (2016).

$\%$ collagen yield $=\frac{\text { Wt of Lyphilized collagen }(\mathrm{gm})}{\text { Wt of Scales }(\mathrm{gm})} \times 100$

\section{Diagnosis of collagen by FT-IR}

Mixing $2 \mathrm{mg}$ of extracted collagen and standard collagen were mixed separately with $\mathrm{KBr}$, then placed in an (FT-IR) device cell, recorded the rays spectra at $(400-4000) \mathrm{cm}^{-1}$. This examination Conducted at the Polymer Research Center, University of Basrah, Iraq, according to the method mentioned in Yan et al. (2008).

\section{Preparation of hydrolysed collagen}

Hydrolysed collagen was prepared according to Giménez et al. (2009) with some modifications. Dissolve $2 \%$ of lyophilised collagen in $0.1 \mathrm{M}$ acetic acid with stirring until the mixture is well homogeneous. Adjust the $\mathrm{pH}$ and the optimum temperature for each enzyme to work (collagenase with specific activity 125 units. $\mathrm{mg}^{-1}$ and pepsin with specific activity 250 units. $\mathrm{mg}^{-1}$. The enzyme was added to the collagen solution at a concentration of 0.1 percent $(w / v)$ and left to hydrolyze for four hours with stirring. The enzymes were inhibited for 10 minutes at $95^{\circ} \mathrm{C}$, followed by 15 minutes of cooling centrifugation at 8000-10000 rpm. Every 30 minutes, the degree of hydrolysis is estimated.

\section{Identification of protein bands}

\section{Degree of hydrolysis}

estimated according to the method mentioned in AOAC (2016). The concentration of metallic elements was calculated using the atomic absorption spectrophotometer (shimadzu, Japan) according to the method (APHA, 1998).
The degree of decomposition was measured with an OPA method (Sigma, USA) by measuring the free amino nitrogen (Church et al., 1983), which is dependent the interaction of the liberated amino groups with the OPA reagent. A $400 \mu \mathrm{l}$ of the sample was added to $3 \mathrm{ml}$ of reagent and left two minutes. Then absorbance was measured at $340 \mathrm{~nm}$. The standard curve of glutathione refers to the released peptide bonds. The degree of degradation is defined as the percentage of peptide bonds released:

DH $=\frac{h}{\text { htot }} \times 100$

As (h) Represent for the number of peptide bonds released.

Htot Represent for the total number of peptide bonds released.

Calculated of Hydrolysis degree according to equation (Nielsen et al., 2001), with some modification:

$\mathrm{DH}=\frac{(\mathrm{X}-\boldsymbol{\beta}) / \boldsymbol{\alpha} \text { megv } / \mathrm{g} \text { protien }}{\text { htot }} \times 100 \%$

$\mathbf{X}=$ values of released peptide bonds extracted from the standard curve equation for glutathione, $\beta, \alpha$ and $h_{\text {tot }}$ stand for constant values for protein raw materials, $\alpha=1 \beta=0.40$ htot $=8.6$

Sodium dodecyl sulfate-polyacrylamide gel electrophoresis (SDS-PAGE) method was 
Al-Abadi \& AI-Temimi / Basrah J. Agric. Sci., 35(1), 94-105, 2022

used to determine the protein bands of both extracted and standardised collagen samples with some modification (Chang et al., 1991; Hames, 1998). 10\% separating gel and 5\% stacking gel were used, the samples were mixed in 5\% SDS solution, they were added to buffer solution (HCL $0.0625 \mathrm{M}$ at $\mathrm{pH} 6.8$, 2\%SDS (w/v), 5\% Mercaptoethanol, 10\% $(\mathrm{v} / \mathrm{v})$ glycerol and $0.002 \%$ bromophenol blue). The samples were heated in a water bath at boiling point for 3 minutes, then cooled and centrifuged for 5 minutes at $10,000 \mathrm{rpm}$. After the migration is complete, inject 101 samples onto an acrylamide gel. Coomassie blue dye was applied to the samples until the bands appeared. Treated samples with Coomassie blue dye until the bands appear. The gel was kept in 5\% acetic acid solution for the appearance of the bands.

\section{Statistical analysis}

Statistical analysis of the results was carried out using a complete randomised design

(CRD) within the Ready Statistical Program (SPSS) and the test of the least significant difference at the level of 0.05 for samples with three replicates (Al-Rawi \& Khalafallah, 2000).

\section{Results \& Discussion}

\section{Chemical content}

Table (1) shows the chemical content of carp fish scales from protein, moisture, ash and fat, as the percentage of moisture and protein was (55.36 and 35.85$) \%$, respectively, while the percentage of fat and ash reached (2.47 and $5.99 \%$ ), respectively. These results are similar to those of Mahboob et al. (2014) who recorded that the chemical composition of common carp scales amounted to 29.91 and $55.13 \%$ for protein and moisture, respectively. Minh-thuy et al. (2014) found that the percentage of protein in the scales of Japanese jack mackerel Trachurus japonicus was $35.50 \%$. Mahboob (2014) noted that the content of Catla catla scales of moisture, protein, fat and ash was $67.36 \%, 22.26 \%$ and $2.88 \%$ and $5.11 \%$, respectively.

Table (1): Chemical content of carp fish scales.

\begin{tabular}{cccc}
\hline Chemical Content of Scales $(\%)$ & \multicolumn{2}{l}{ Minerals elements $\mu \mathrm{g}^{-1}$} \\
\hline moisture & $55.36 \pm 0.05$ & $\mathrm{Ca}$ & $153430 \pm 3$ \\
\hline protein & $35.85 \pm 0.04$ & $\mathrm{P}$ & $1887.5 \pm 0.1$ \\
\hline Fat & $2.47 \pm 0.03$ & $\mathrm{Fe}$ & $71.455 \pm 0.002$ \\
\hline Ash & $5.99 \pm 0.01$ & $\mathrm{Zn}$ & $48.045 \pm 0.004$ \\
\hline & *The results are an average of three replicates
\end{tabular}

Table (1) shows the $\mathrm{Ca}, \mathrm{P}, \mathrm{Fe}$ and $\mathrm{Zn}$ concentration in common carp scales 153430 , 1887.5, 71.455 and $48.045 \mu \mathrm{g} \cdot \mathrm{g}^{-1}$, respectively. The difference in the concentrations of minerals elements may be attributed to too many biological factors such as environment, water, location of the food chain, and physiological characteristics of fish. Toppe et al. (2007) that the concentration of the minerals calcium, phosphorous, iron and zinc in the bones of mackerel and trout $\left(233 \mathrm{~g} . \mathrm{kg}^{-1}, 111 \mathrm{~g} \cdot \mathrm{kg}^{-1}, 56\right.$ mg.kg ${ }^{-1}, 70$ mg.kg $\left.{ }^{-1}\right)$ and $(147$ g.kg-1, 87 g.kg 1, $32 \mathrm{mg} \cdot \mathrm{kg}^{-1}$ and $\left.126 \mathrm{mg} \cdot \mathrm{kg}^{-1}\right)$, respectively. 
Al-Abadi \& AI-Temimi / Basrah J. Agric. Sci., 35(1), 94-105, 2022

Yield and protein content of the collagen

Table (2) demonstrates the collagen output yield of carp fish scales extracted with $0.05 \mathrm{M}$ acetic acid, $0.1 \%$ pepsin enzyme, and the protein content of collagen. The results of the statistical analysis showed that the percentage of the yield differed significantly depending on the method of extraction at ( $\mathrm{p}<0.05)$, as the percentage of the yield was 16.40 and $5.30 \%$, respectively. The difference in yield percentage between the enzymatic and acid extraction methods could be attributable to the effectiveness or quantity of pepsin utilized, which varies depending on the fish species and collagen composition. Or it may be attributed to the fact that the collagen extracted by the acidic method did not completely dissolve when treated with $0.5 \mathrm{M}$ acetic acid compared to Using the enzyme that caused its complete dissolution. According to a study, collagen cross-links through covalent connections as well as molecular bonding in the telopeptide region, resulting in a decrease in collagen solubility with acid compared to enzymatic treatment (Singh et al., 2011). These results were higher than what was found by Bhagwat \& Dandge (2016) when extracting collagen by acidic method from the scales of common carp, which amounted to $9.79 \%$. Wu et al. (2019) found that the collagen yield of Hypophthalmichthys molitrix fish scales was 5.09. Matmaroh et al. (2011) reported that the yield of collagen extracted by the enzymatic method from the scales of the golden-spotted goatfish Parupeneus heptacanthus was 1.20\%. Chuaychan et al. (2015) indicated that the collagen extracted from the scales of the seabass Lates calcarifer was $1.06 \%$.

The proportion of protein in collagen extracted with acid and enzyme was 92.07 percent and 92.41 percent, respectively, according to the table. With a protein concentration of 93.56 percent, the results were identical to those obtained by Wang et al. (2013) when extracting collagen from Croceine Croaker fish scales. Because of the high collagen production and the high proportion of protein recovered using acidic methods.

\section{Diagnostics of amide compounds by FT-IR technology}

The wavenumber and infrared spectrograph of the amide groups of the ASC and standard collagen are shown in table (3), figs. (1 and 2).

Table (2): yield and protein content of collagen extracted from common carp scales.

\begin{tabular}{lr}
\hline \multicolumn{2}{c}{ Yield } \\
\hline$(\%)$ the protein of acid- soluble collagen (ASC) & $92.07 \pm 0.01^{\mathrm{a}}$ \\
\hline$(\%)$ the protein of Pepsin soluble collagen (PSC) & $92.41 \pm 0 .^{01 \mathrm{a}}$ \\
\hline acid soluble collagen (ASC) & $16.40 \pm 0.02^{\mathrm{a}}$ \\
\hline Pepsin soluble collagen(PSC) & $5.30 \pm 0.01^{\mathrm{b}}$ \\
\hline
\end{tabular}

*a, b Means in a column followed by different letters differ significantly $(\mathrm{P}<0.05)$

The amides A, B, I, II, and III for ASC are at wavenumbers $3413.39 \mathrm{~cm}-1$ and 2924.52 $\mathrm{cm}-1,1653.66 \mathrm{~cm}-1,1548.56 \mathrm{~cm}-1$, and 1240 cm-1, respectively, according to the table. Standard collagen's amide bands A, B, I, II, 
Al-Abadi \& AI-Temimi / Basrah J. Agric. Sci., 35(1), 94-105, 2022

and III appeared at wavenumbers 34 and 35, respectively.

The results also revealed that the ratio between amide III and the wavenumber 1454 cm-1 is 1.17 for both acid-extracted collagen and standard collagen, which is close to 1.0, indicating that collagen has a helical structure. A number of studies have found that amide III determines collagen's helix structure; as the more the ratio approaches 1.0 , it indicates the helix structure of collagen (Sionkowska et al., 2015; He et al., 2019). The result was in agreement with Chen et al. (2016) observed the ratio between the absorption of amide III and $1454 \mathrm{~cm}^{-1}$ for collagen extracted with pepsin from the scales of red drum Sciaenops ocellatus ranged 1-1.1, which indicates the integrity of the helical structure of collagen.

Table (3): Wave numbers and effective groups of ASC and standard collagen estimated by the technology of FT-IR amide type.

\begin{tabular}{|c|c|c|c|}
\hline Amide type & $\begin{array}{c}\text { Wavenumber } \mathrm{cm}^{-1} \text { for ASC } \\
\text { collagen }\end{array}$ & $\begin{array}{c}\text { Wavenumber } \mathrm{cm}^{-1} \text { for standard } \\
\text { collagen }\end{array}$ & $\begin{array}{c}\text { Effective } \\
\text { group }\end{array}$ \\
\hline A & 3413.39 & 3413.39 & $\mathrm{~N}-\mathrm{H}$ \\
\hline B & 2924.52 & 2924.52 & $\mathrm{CH}_{2}$ \\
\hline I & 1653.66 & 1642.09 & $\mathrm{C}=\mathrm{O}$ \\
\hline II & 1548.56 & 1564.95 & $\mathrm{~N}-\mathrm{H}, \mathrm{C}-\mathrm{N}$ \\
\hline III & 1240 & 1241.39 & $\mathrm{NH}, \mathrm{C}-\mathrm{N}$ \\
\hline
\end{tabular}

A, B, I, II, III: amide bands infrared spectroscopy (FTIR) of scale collagen and standard collagen.

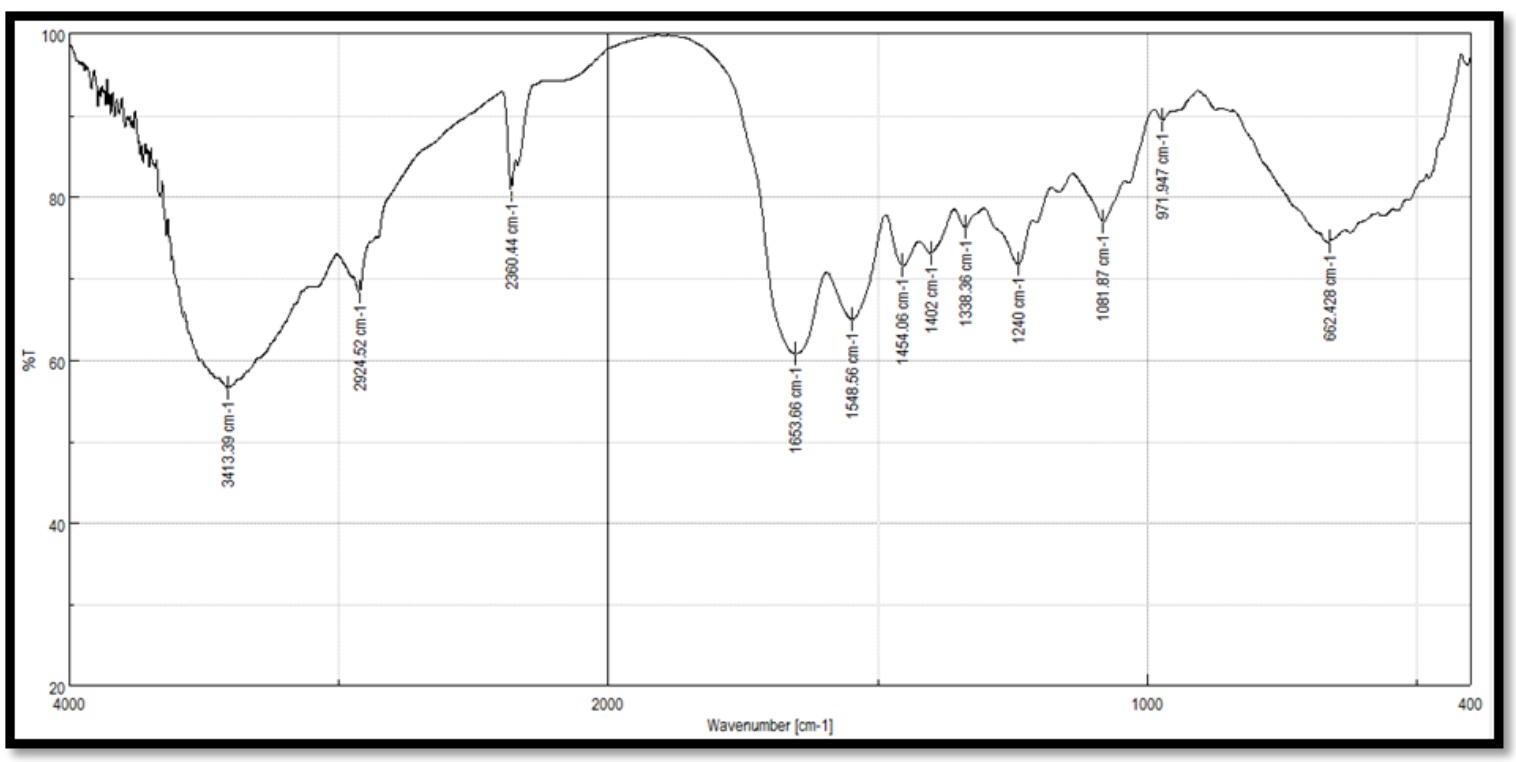

Fig. (1): FT-IR spectrum of ASC. 
Al-Abadi \& AI-Temimi / Basrah J. Agric. Sci., 35(1), 94-105, 2022

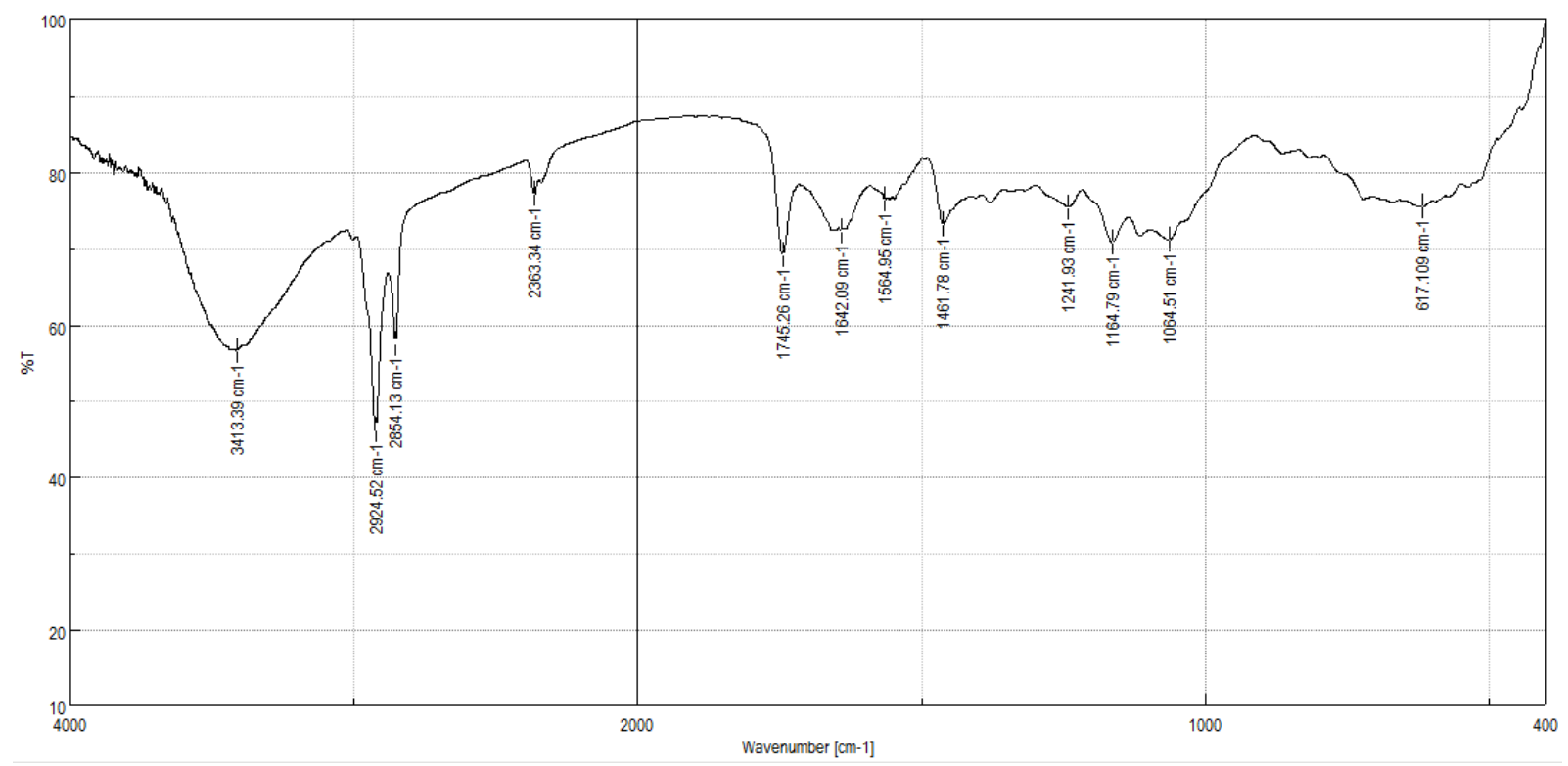

Fig. (2): FT-IR Spectrum of Standard Collagen.

The appearance of the amide band A occurred because of the elastic vibration of the $\mathrm{NH}$ group in the range $3400-3440 \mathrm{~cm}^{-1}$. At the same time, the amide band B formed due to the asymmetric elastic vibration of the $\mathrm{CH} 2$ group. The band I was caused by the stretching vibration of the carbonyl group $\mathrm{C}=\mathrm{O}$, which indicates the secondary structure of the peptide. The presence of band II occurred as a result of the bending vibrations of the NH group and the stretching vibration of the CN group, and it should be noted that the appearance of this band in ASC at wavenumber $1500-1600 \mathrm{~cm}^{-1}$ is evidence that the hydrogen bonds in collagen are abundant and strongly interconnected. These results were confirmed by (Chen et al., 2016). The presence of the amide III bands in ASC attributed to the vibration of the flexural plane of the NH group and the stretchy vibration of the $\mathrm{CN}$ group resulting from the amide bonds and the absorption resulting from the oscillatory vibration of the $\mathrm{CH}_{2}$ group, these results agreement with (Sionkowska et al., 2015 ; He et al., 2019). Zhang et al. (2009) mentioned that amide III is responsible for fusing the $\mathrm{NH}$ and $\mathrm{CN}$ group jointly along with the triple helix. According to Bet et al. (2001) the existence of peaks near wavenumber $1454 \mathrm{~cm}^{-1}$ shows the vibrations of the pyrrolidine ring of proline and hydroxyproline. These results agreed with several studies (Krimm \& Bandekar, 1986; Payne \& Veis, 1988; Surewicz \& Mantsch, 1988).

\section{Degree of hydrolysis}

Fig. (3) shows the degree of hydrolysis of ASC after 240 minutes of treatment with Collagenase and Pepsin enzymes at the optimum temperature and $\mathrm{pH}$ for each enzyme. For 0 to 120 minutes, a progressive increase was seen, with the highest degree of hydrolysis 27.21 percent after two hours of treatment with collagenase, which was thereafter inhibited. The Pepsin enzyme was then introduced, and it was discovered that by following up on the degree of hydrolysis significantly increased after 30 minutes of treatment, this increase continued until it reached $43.56 \%$ for 240 minutes. The high degree of hydrolysis after adding pepsin may be attributed to the fact that collagenase is a specialised enzyme that cleaves the helical peptide chains of collagen and converts them into chains that make it easier for the 
Al-Abadi \& AI-Temimi / Basrah J. Agric. Sci., 35(1), 94-105, 2022

proteases to reach and attack them, splitting amino acids and smaller units. large peptides and converting them into

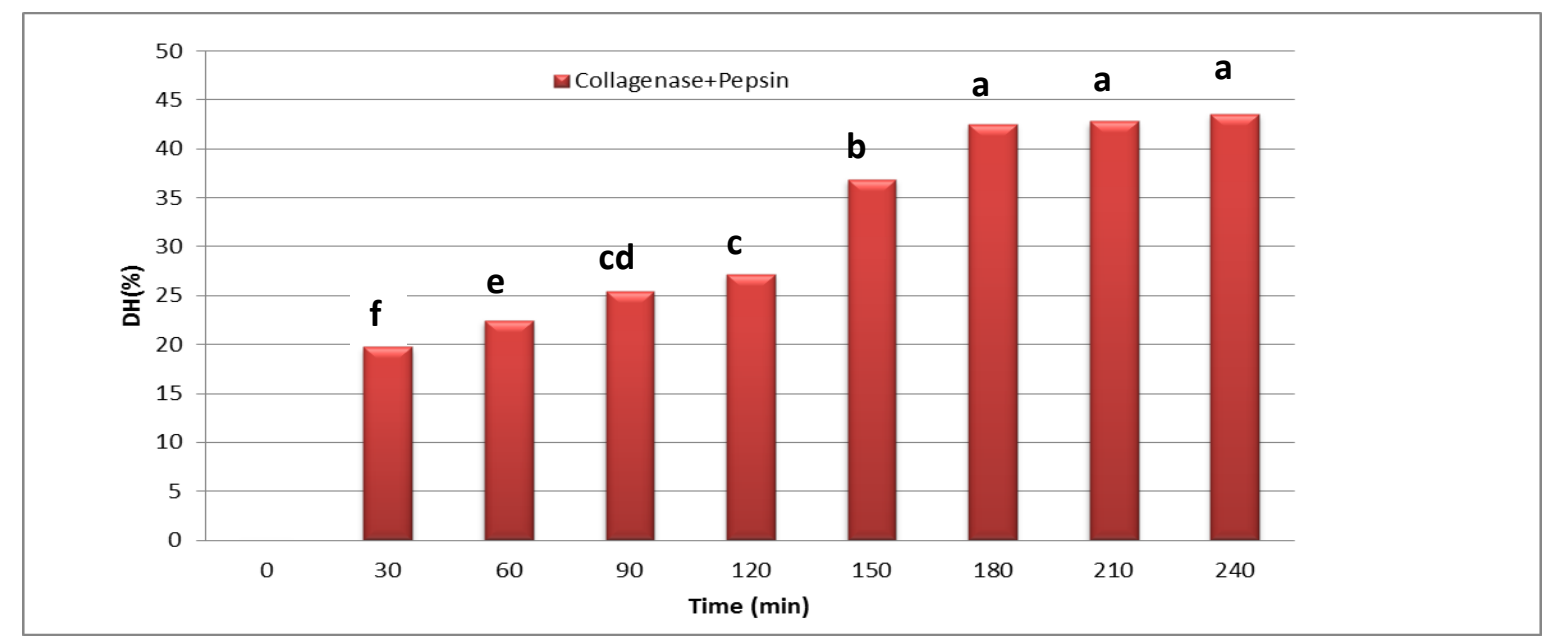

$* * \mathrm{a}, \mathrm{b}, \mathrm{c}, \mathrm{d}, \mathrm{e}, \mathrm{f}$ Means in a column followed by different letters differ significantly $(\mathrm{P}<0.05)$

Fig. (3): Collagen hydrolysates by collagenase + pepsin enzymes.

Wang et al. (2013) found that the degree of hydrolysis by pepsin and trypsin enzymes with each other at concentrations $2.5 \%$ and $3 \%$, respectively, a period of four hours for collagen extracted from the scales of large yellow crocker Pseudosciaena crocea (Larimichthys crocea) reached $25.11 \%$.

Yi et al. (2016) noted that the degree of hydrolysis of collagen prepared from the skin of grass carp using Collagenase enzyme followed by Trypsin enzyme reached $13.80 \%$ for three hours. According to these studies, Collagenase's function is limited to cleaving the peptide chains of the triple helical structure of collagen, then converting the chains that become easy for proteolytic enzymes to access and attack.

\section{Electrophoresis}

The electrophoresis method will diagnose the collagen bands by polyacrylamide with existence SDS for standard collagen, ASC, and PSC. Fig. (4) shows the occurrence of three protein bands represented by $\alpha_{1}, \alpha_{2}$, and $\beta$ with molecular weights of 126,100 , and $180 \mathrm{KD}$ for ASC and PSC, respectively. In contrast, the standard collagen showed the presence of two $\alpha_{1}$ and $\alpha_{2}$ bands with a molecular weight of 130 and $126 \mathrm{KD}$, respectively. Terzi et al. (2019) pointed that the existence of different bands of $\alpha$ indicates that collagen is a type I, the absence of any other types of protein refer to the purity of collagen. Many investigations had found that the collagen of bighead carp Hypophthalmichthys nobilis scales had two $\alpha_{1}$ and $\alpha_{2}$ bands with a molecular weight of 126 and $116 \mathrm{KD}$, respectively, and two different chains of $\beta$ (Liu et al., 2012). The electrophoresis of collagen enzymatically extracted from the scales of Oreochromis niloticus showed three bands $\alpha_{1}, \alpha_{2}$, and $\beta$ with molecular weight 128,123 , and $200 \mathrm{KD}$, respectively, which indicated that type of I collagen (El-Rashidy et al., 2015). 
Al-Abadi \& AI-Temimi / Basrah J. Agric. Sci., 35(1), 94-105, 2022

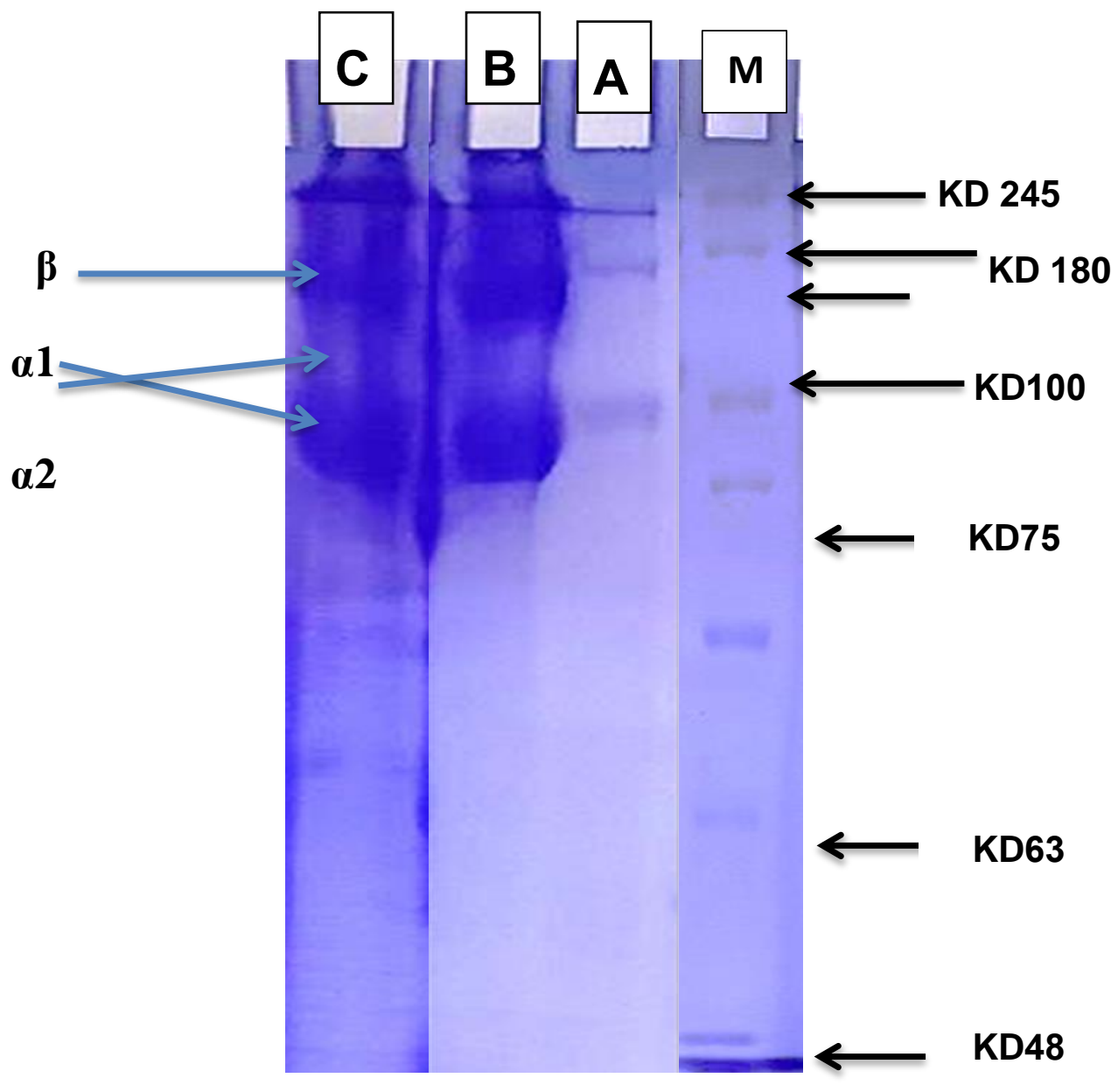

KD63

Fig. (4): Electrophoresis - (A) Standard Collagen, (B) ASC, (C) PSC. (M) Standard Proteins

\section{Conclusion}

The results were concluded from the current study that it is possible to exploit fish waste, especially fish scales, to produce compounds of high commercial value represented by collagen. As well could be produce hydrolyzed collagen that is safe for consumption and bioactive that utilized as a nutritional or pharmaceutical supplement.

\section{Acknowledgements}

We offer sincere thanks and appreciation to the staff of the Department of Food Sciences. We would like to thanks the Polymer
Research Centre, University of Basrah, for assistance in the analysing of samples.

Conflicts of Interest: The authors declare no conflicts of interest.

ORCID: W. A. Al-Temimi https://orcid.org/00000003-2428-790X

\section{References}

Al-Rawi, K. M., \& Khalafallah, A. M. (2000). Design and Analysis of Agricultural Experiments. 2nd edition, The Book House for Printing and Publishing. University of Mosul, 488pp. (In Arabic).

AOAC. (2016). Official methods of anaylsis. Retrieved from http://www.eoma.aoac.org/metho ds/info.asp?ID=16264 


\section{Al-Abadi \& AI-Temimi / Basrah J. Agric. Sci., 35(1), 94-105, 2022}

APHA (American Public Health Association). (1998). Standard Methods for the Examination of water and wastewater. 20th Edition, American Public Health Association, New York.

Arvanitoyannis, I. S., \& Kassaveti, A. (2008). Fish industry waste: treatments, environmental impacts, current and potential uses. International Journal of Food Science \& Technology, 43(4), 726-745. https://doi:10.1111/j.1365-2621.2006.01513.x

Bet, M. R., Goissis, G., \& Lacerda, C. A. (2001). Characterization of polyanionic collagen prepared by selective hydrolysis of asparagine and glutamine carboxyamide side chains. Biomacromolecules, 2(4), 1074-1079. https://doi:10.1021/bm0001188

Bhagwat, P. K., \& Dandge, P. B. (2016). Isolation, characterization and valorizable applications of fish scale collagen in food and agriculture industries. Biocatalysis and Agricultural Biotechnology, 7, 234-240. https://doi:10.1016/j.bcab.2016.06.010

Chang, G. G., Wang, J. K., Huang, T. M., Lee, H. J., Chou, W. Y., \& Meng, C. L. (1991). Purification and characterization of the cytosolic NAD dependent malic enzyme from human cancer cell line. European Journal of Biochemistry, 202(2), 681-688. https://doi:10.1111/j.14321033.1991.tb16423.x

Chen, S., Chen, H., Xie, Q., Hong, B., Chen, J., Hua, F., Bai, K., He, J., Yi, R., \& Wu, H. (2016). Rapid isolation of high purity pepsin-soluble type i collagen from scales of red drum fish (Sciaenops ocellatus). Food Hydrocolloids, 52, 468-477. https://doi:10.1016/j.foodhyd.2015.07.027

Chuaychan, S., Benjakul, S., \& Kishimura, H. (2015). Characteristics of acid- and pepsin-soluble collagens from scale of seabass (Lates calcarifer). LWT -Food Science and Technology, 63(1), 71-76. https://doi:10.1016/j.lwt.2015.03.002

Church, F. C., Swaisgood, H. E., Porter, D. H., \& Catignani, G. L. (1983). Spectrophotometric assay using o-phthaldialdehyde for determination of proteolysis in milk and isolated milk proteins. Journal Dairy Science, 66, 1219-1227. https://doi:10.3168/jds.s0022-0302(83)81926-2

Denis, A., Brambati, N., Dessauvages, B., Guedj, S., Ridoux, C., Meffre, N., \& Autier, C. (2008). Molecular weight determination of hydrolyzed collagens. Food Hydrocolloids, 22(6) 989-994. https://doi:10.1016/j.foodhyd.2007.05.016

El-Rashidy, A. A., Gad, A. Y., Abu-Hussein, A. E. H. G., Habiba, S. I., Badr, N. A., \& Hashem, A. A. (2015). Chemical and biological evaluation of Egyptian Nile Tilapia (Oreochromis niloticas) fish scale collagen. International Journal of Biological Macromolecules, $\quad 79, \quad 618-626$. https://doi:10.1016/j.ijbiomac.2015.05.019

Fehing, S. P. C. (2016). Extraction of collagen from fish wastes, optimization and characterization. M. Sc. Thesis. University of Tunku Abdul Rahman, Malaysia.

Giménez, B., Alemán, A., Montero, P., \& GómezGuillén, M. C. (2009). Antioxidant and functional properties of gelatin hydrolysates obtained from skin of sole and squid. Food Chemistry, 114(3), 976-983.

https://doi:10.1016/j.foodchem.2008.10.050

Hames, B.D. (1998). Gel electrophoresis of proteins. $3^{\text {rd }}$ : A practical approach. Oxford University Press. P. 373pp.

He, L., Lan, W., Wang, Y., Ahmed, S., \& Liu, Y. (2019). Extraction and characterization of selfassembled collagen isolated from grass carp and crucian carp. Foods, 8(9), 396-410. https://doi:10.3390/foods8090396

Krimm, S., \& Bandekar, J. (1986). Vibrational Spectroscopy and Conformation of Peptides, Polypeptides, and Proteins. Advances in Protein Chemistry, 38, 181-364. https://doi.org/10.1016/S00653233(08)60528-8

Liu, D., Liang, L., Regenstein, J. M., \& Zhou, P. (2012). Extraction and characterisation of pepsinsolubilised collagen from fins, scales, skins, bones and swim bladders of bighead carp (Hypophthalmichthys nobilis). Food Chemistry, 133(4), 1441-1448. https://doi:10.1016/j.foodchem.2012.02.032

Mahboob, S. (2014). Isolation and characterization of collagen from fish waste material- skin, scales and fins of Catla catla and Cirrhinus mrigala. Journal of Food Science and Technology, 52(7), 4296-4305. https://doi:10.1007/s13197-014-1520-6

Mahboob, S., Haider, S., Sultana, S., Al- Ghanim, K. A., Al-Misned, F., Al-Kahem Al-Balawi, H. F., \& Ahmad, Z. (2014). Isolation and characterisation of collagen from the waste material of two importnt freshwater fish species. The Journal of Animal and Plant Sciences, 24(6), 1802-1810.

Matmaroh, K., Benjakul, S., Prodpran, T., Encarnacion, A. B., \& Kishimura, H. (2011). Characteristics of acid soluble collagen and pepsin soluble collagen from scale of spotted golden goatfish (Parupeneus heptacanthus). Food Chemistry, 129(3), 1179-1186. https://doi:10.1016/j.foodchem.2011.05.099 


\section{Al-Abadi \& AI-Temimi / Basrah J. Agric. Sci., 35(1), 94-105, 2022}

Minh-thuy, L. T., Okazaki, E., \& Osako, K. (2014). Isolation and characterization of acid-soluble collagen from the scales of marine fishes from Japan and Vietnam. Food Chemistry, 149, 264-270. https://doi:10.1016/j.foodchem.2013.10.094

Nagai, T., Yamashita, E., Taniguchi, K., Kanamori, N., $\&$ Suzuki, N. (2001). Isolation and characterisation of collagen from the outer skin waste material of cuttlefish (Sepia lycidas). Food Chemistry, 72(4), 425-429. https://doi:10.1016/s0308-8146(00)002491

Nielsen, P. M., Petersen, D., \& Dambmann, C. (2001). Improved method for determining food protein degree of hydrolysis. Journal of Food Science, 66(5), 642-646. https://doi.org/10.1111/j.13652621.2001.tb04614.x

Olatunji, O., \& Denloye, A. (2017). Temperaturedependent extraction kinetics of hydrolyzed collagen from scales of croaker fish using thermal extraction. Food Science and Nutrition, 5(5), 10151020. https://doi:10.1002/fsn3.488

Payne, K. J., \& Veis, A. (1988). Fourier transform IR spectroscopy of collagen and gelatin solutions: deconvolution of the amide $I$ band for conformational studies. Biopolymers, 27(11), 17491760. https://doi: 10.1002/bip.360271105

Shoulders, M. D., \& Raines, R. T. (2009). Collagen structure and stability. Annual Review of Biochemistry, 78(1), 929-958. https://doi.org/10.1146/annurev.biochem.77.032207 .120833

Singh, P., Benjakul, S., Maqsood, S., \& Kishimura, H. (2011). Isolation and characterisation of collagen extracted from the skin of striped catfish (Pangasianodon hypophthalmus). Food Chemistry, 124(1), 97-105. https://doi:10.1016/j.foodchem.2010.05.111

Sionkowska, A., Kozłowska, J., Skorupska, M., \& Michalska, M. (2015). Isolation and characterization of collagen from the skin of Brama australis. International Journal of Biological Macromolecules, $\quad 80, \quad 605-609$. https://doi:10.1016/j.ijbiomac.2015.07.032

Sorushanova, A., Delgado, L. M., Wu, Z., Shologu, N., Kshirsagar, A., Raghunath, R., Mullen, A. M., Bayon, Y., Pandit, A., Raghunath, M., \& Zeugolis, D. I. (2018). The collagen suprafamily: From biosynthesis to advanced biomaterial development. Advanced Materials, 31(1), 1801651-1801690. https://doi:10.1002/adma.201801651

Surewicz, W. K., \& Mantsch, H. H. (1988). New insight into protein secondary structure from resolution-enhanced infrared spectra. Biochimica et Biophysica Acta (BBA) - Protein Structure and Molecular Enzymology, 952, 115-130. https://doi:10.1016/0167-4838(88)90107-0

Terzi, A., Gallo, N., Bettini, S., Sibillano,T., Altamura, D., Campa, L., Natali, M. L.,Salvatore, L., Madaghiele, M., Caro, L. D., Valli, L., Sannion, A., \& Giannini, C.(2019). Investigations of processing-induced structural changes in horse type-i collagen at sub and supramolecular levels. Frontiers in Bioengineering and Biotechnology, 7, 303-318. https://doi:10.3389/fbioe.2019.00203

Toppe, J., Albrektsen, S., Hope, B., \& Aksnes,A.(2007). Chemical composition, mineral content and amino acid and lipid profiles in bones from various fish species. Comparative Biochemistry and Physiology Part B: Biochemistry and Molecular Biology, 146(3), 395-401. https://doi:10.1016/j.cbpb.2006.11.020

Udenigwe, C. C., \& Aluko, R. E. (2011). Food ProteinDerived Bioactive Peptides: Production, Processing, and Potential Health Benefits. Journal of Food Science, $\quad 77(1), \quad$ R11-R24. https://doi:10.1111/j.1750-3841.2011.02455.x

Wang, B., Wang, Y.M., Chi, C.F., Luo, H.Y., Deng, S. G., \& Ma, J. Y. (2013). Isolation and characterization of collagen and antioxidant collagen peptides from scales of croceine croaker (Pseudosciaena crocea). Marine Drugs, 11(11), 4641-4661. https://doi:10.3390/md11114641

Wu, J., Kong, L., Zhang, J., \& Chen, W. (2019). Extraction and properties of acid-soluble collagen and pepsin-soluble collagen from silver carp (Hypophthalmichthys molitrix) scales: Prerequisite information for fishery processing waste reuse. Polish Journal of Environmental Studies, 28(4), 2923-2930. https://doi.org/10.15244/pjoes/93742

Yan, M., Li, B., Zhao, X., Ren, G., Zhuang, Y., Hou, H., Zhang, X., Chen, L., \& Fan, Y. (2008). Characterization of acid-soluble collagen from the skin of walleye pollock (Theragra chalcogramma). Food Chemistry, 107(4), 1581-1586. https://doi:10.1016/j.foodchem.2007.10.027

Yi, J., De Gobba, C., Skibsted, L. H., \& Otte, J. (2016). Angiotensin-I converting enzyme inhibitory and antioxidant activity of bioactive peptides produced by enzymatic hydrolysis of skin from grass carp (Ctenopharyngodon idella). International journal of food properties, 20(5), 1129-1144. https://doi:10.1080/10942912.2016.1203932

Zhang, J., Duan, R., Ye, C., \& Konno, K. (2010). Isolation and characterization of collagens from 
Al-Abadi \& AI-Temimi / Basrah J. Agric. Sci., 35(1), 94-105, 2022

scale of silver carp (Hypophthalmichthys molitrix).

Journal of Food Biochemistry, 34(6), 1343-1354. https://doi: 10.1111/j.1745-4514.2010.00439.x

Zhang, M., Liu, W., \& Li, G. (2009). Isolation and characterization of collagens from the skin of largefin longbarbel catfish (Mystus macropterus).

Food Chemistry, 115(3), 826-831. https://doi.org/10.1016/j.foodchem.2009.01.006

\title{
انتاج متحلل كولاجيني من قثشور سمك الكارب Cyprinus carpio بالنظم الانزيمية المتازرة
}

\author{
حلا هاني محمد العبادي 1 و وسن كاظم عبدالرزاق التميمي2 \\ مديرية زراعة البصرة، البصرة العراق \\ 2ققم علوم الاغذية، كلية الزر اعة، جامعة البصرة، العراق
}

المستخلص: تعد جلود الأسماك و عظامها وقثور ها مصدرًا جيدًا للكو لاجين ، من أجل استغلال المخلفات السمكية وتحويلها إلى منتجات غذائية وعلاجية وصيدلانية ذات قيمة تجارية عالية ـ لذا شملت الدراسة استخلاص الكو لاجين بحامض الخليك بتركيز 0.5 مو لار و إنزيم البييسين 0.1\% من قشور سمك Cyprinus carpio ثم درست قابلية إنتاج المتحلل الكولاجيني. قدر المحتوى

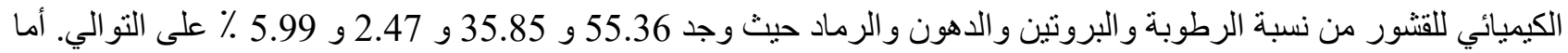

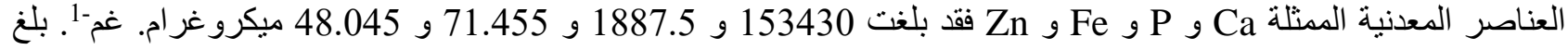

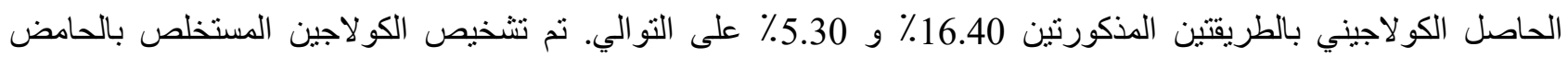

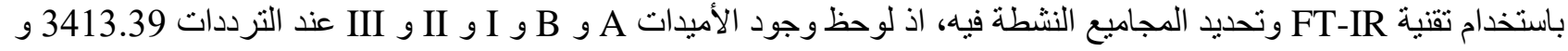

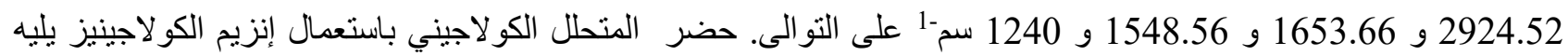

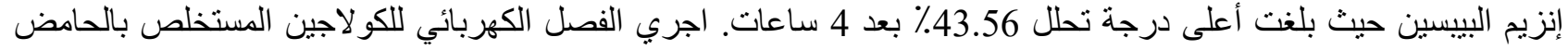

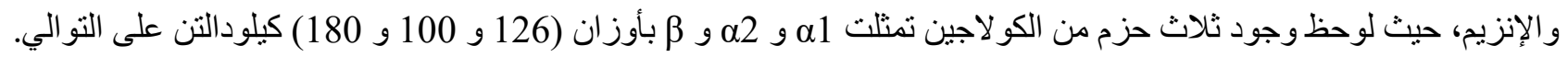

